\title{
The Impact of Ownership Structure on Capital Structure: An Empirical Study on the Most Active Firms in the Egyptian Stock Exchange
}

\author{
Mohamed Fayez, Aiman A. Ragab, Mohamed Moustafasoliman \\ The Arab Academy for Science and Technology \& Maritime Transport, Alexandria, Egypt \\ Email: Mohamed.Fayez@aast.edu, aaragab@aast.edu, Mohamed.soliman@aast.edu
}

How to cite this paper: Fayez, M., Ragab, A.A. and Moustafasoliman, M. (2019) The Impact of Ownership Structure on Capital Structure: An Empirical Study on the Most Active Firms in the Egyptian Stock Exchange. Open Access Library Journal, 6: e5266.

https://doi.org/10.4236/oalib.1105266

Received: February 20, 2019

Accepted: September 2, 2019

Published: September 5, 2019

Copyright $\odot 2019$ by author(s) and Open Access Library Inc.

This work is licensed under the Creative Commons Attribution International License (CC BY 4.0).

http://creativecommons.org/licenses/by/4.0/

\begin{abstract}
This study aims to find the most relative ownership structure related factors of influencing capital structure of top 50 non-financial firms listed in Egyptian exchange from 2012 to 2017 . The study found that the hypotheses from one to six that are explaining the relationship between Ownership Structure and Capital Structure are partially supported. Also, the study explaining the effect of Firm Age and Company Size on Capital Structure is partially supported.
\end{abstract}

\section{Subject Areas}

Managerial Economics

\section{Keywords}

Managerial Ownership, State Ownership, Foreign Ownership, Block Ownership, Institutional Ownership, Ownership Concentration, Capital Structure

\section{Introduction}

The relationship between ownership and capital structures has attracted considerable research attention over the last couple of decades. Ownership structure was defined in terms of capital contributions [1]. Thus, the authors saw ownership structure to comprise of inside equity (managers), outside equity and debt, thus proposing an extension of the form of ownership structure beyond the debt-holder and equity-holder view. Unlike other authors, ownership structure was constructed using variables including proportion of foreign share ownership, managerial ownership percentage, largest institutional shareholder owner- 
ship, largest individual ownership, and government share ownership [2]. It was suggested that ownership is positively correlated with various measures of the debt-equity ratio (leverage), implying that ownership structure has a correlation with financial structure of firms [3]. It was found that debt ratio is negatively related to managerial ownership [4]. It was suggested that the relationship between managerial share ownership and leverage may in fact be inverted u-shaped [5]. Thus, debt first increases with an increase in managerial share ownership; but beyond a critical level of managerial share ownership debt may fall because there could be only a few agency related benefits by increasing debt further as the interests of managers and owners get very strongly aligned.

It was concluded that insider ownership does not affect debt when the interest of managers and owners are aligned [6]. In relating capital structure to the level of compensation for CEOs came out with the findings that there is a positive correlation between the two [1] and this was supported by [7] and [8] who assert the claim that the correlation between CEO compensation and capital structure is a positive one. However, a negative correlation between CEO compensation and the financial leverage of firms was found [4] [9]. It was argued that family ownership may give rise to greater leverage than in the case of disperse ownership, because of the non-dilution of entrenchment effects [10]. An empirical evidence was documented that funding family-controlled firms use less debt than non-funding family-controlled firms [11]. This research seeks to fill the gap of measuring such relationships in an emerging economy such as Egypt. It is examining the relationship between ownership structure and capital structure in Egypt by investigating the impact of ownership concentration and its different categories (managerial ownership, state ownership, foreign ownership, block ownership, institutional ownership) on capital structure of the most active 50 non-financial Egyptian listed companies for the period 2012-2017.

\section{Literature Review}

We will review and discuss the prior literature on ownership structure tributes and capital structure. Since ownership structure can be studied under various theories.

\subsection{Managerial Ownership and Capital Structure}

Capital structure decision is affected not only by firm characteristics or contextual factors, but also by managers' views, goals and desires, which are influenced by managerial ownership structure [5]. The rationale for explaining the positive influence of managerial ownership on capital structure relates to the issue of control [12]. A major concern for managers is retaining or increasing their control because it provides them with discretion in making decisions and access to private benefits. Meanwhile, debt is a means to avoid share dilution. It was affirmed that an increase in debt helps managers to reinforce their control and resist takeovers [13]. 
Managers sometimes use excess debt as a transitory device to signal a covenant to sell assets, thereby preventing takeover attempts from outside investors. In addition, with high debt, managers have more cash to pursue suboptimum investments for their own interests. In some of the first empirical evidence, it was found that firms with higher insider ownership have greater debt levels than those with lower insider ownership [14]. Their methodology was to use both analysis of variance and regression techniques to compare long-term debt to total capitalization of firms that have high inside ownership with those that have low inside ownership. Depending on the above discussion, the next hypothesis was developed; $H 1$ There is a significant relationship between Managerial ownership and capital structure.

\subsection{State Ownership and Capital Structure}

Here has been a growing interest in research on the linkage between ownership structure and capital structure, but there continues to be limited evidence on the association between capital structure and state ownership for transition economies that have undertaken an equitation process. Conducting a study on listed Chinese firms, it was argued that state ownership is positively related to debt ratio for three reasons [15]. First, firms with high state ownership may have better access to the debt market because they have less chance of bankruptcy because of the guarantee of the state. Second, representatives of state ownership might prefer to have a high level of debt to avoid share dilution or to preserve their control. Third, agency problems between owners and managers tend to be severe in firms with a high level of state ownership because there is segregation between voting and cash flow rights.

While the ultimate owners of state-owned shares are the citizens, the voting rights belong to government departments or bureaucrats whose salaries are normally not directly linked to the performance of the firms that they monitor and control. As a result, bureaucrats are not motivated to manage firm operations efficiently.

Therefore, to reduce considerable agency costs of equity, state-controlled firms tend to use high debt as a monitoring channel. A study conducted on non-publicly traded Chinese firms indicated a positive relationship between state ownership, measured by the fraction of shares held by state, and all measures of leverage, including short-term, long-term and total debt to total assets [16]. They found that the high degree of state ownership can enhance a firm's access to debt because of soft budget constraints and bailouts from the government.

Investigating a sample of 95 Russian listed firms from 2000 to 2004, it was also found that firms with high state ownership have a significantly higher debt level than others [17]. This result implies that firms with other types of ownership do not have equal access to capital sources. Specifically, state-owned firms may have substantial advantages with respect to access to the debt market because of the 
preferential treatment they receive from state-owned banks. For example, while other private firms must rely on capital sources with high costs, state-owned firms can obtain debt financing at a low cost. As a result, they can use more debt than other corporations in general. Depending on the above discussion, the next hypothesis was developed;

$H 2$ There is a significant relationship between State ownership and capital structure

\subsection{Foreign Ownership and Capital Structure}

In emerging markets, because of booming foreign investment inflow, the influence of foreign investors on firms' activities is increasing; however, little research has been conducted using a detailed dataset to examine the link between foreign ownership and the capital structure decisions of a firm. Most studies in this area posit that there is a negative relationship between foreign ownership and debt level, except for the studies of [15] and [18]. These studies hypothesized a positive effect of foreign ownership on capital structure; nevertheless, contrary to their predictions, their study findings indicate a negative association between foreign ownership and capital structure. More specifically, it was that believed that in emerging markets foreign investors normally face more severe information asymmetry than other investors and that foreign investors often have a diversified portfolio in which the percentage of shareholding in each firm is generally low [15]. Therefore, the power of foreign investors to monitor management is not sufficient, forcing firms to use more debt as a further management monitoring mechanism. Nonetheless, in their investigation of the financing behavior of Chinese public listed companies from 1997 to 2000, [15] did not find a significant influence of foreign ownership on capital structure.

It was contended that foreign investors normally suffer more types of risks, including country risk, currency risk and business risk, than domestic investors [18]. As a result, foreign investors are motived to minimize their risk by influencing the operations of firms in which they have invested through bringing not only their capital but also their technology and ability to access new capital markets. Therefore, it was expected that firms with high foreign ownership could use more debt because foreign investors help them to access more and cheaper debt from new creditors.

However, when testing the effect of foreign ownership on capital structure using multivariate regression analysis with a dataset of 143 non-financial firms listed on the Istanbul Stock Exchange from 2007 to 2008, it was found that foreign ownership (percentage of shares owned by foreign shareholders) is significantly negatively related to long-term leverage. They explained this result by a reason that the need for external financing like debt of firms with high foreign ownership decreases due to the equity contribution from foreign investors [18].

Conducting research in non-publicly traded Chinese firms, it was found that foreign ownership, measured as the fraction of ownership by foreign investors, is negatively related to all measures of leverage, including total debt, short-term 
debt and long-term debt divided by total assets [16]. This result was explained by two factors. First, firms with high foreign ownership have more diversified financing channels to access capital than others because of their reputations and relationships. Second, in China, foreign-owned firms normally have lower corporate tax rates than others; therefore, they tend to use less debt because of the low of tax-shield saving. Depending on the above discussion, the next hypothesis was developed;

$H 3$ There is a significant relationship between foreign ownership and capital structure

\subsection{Block Ownership and Capital Structure}

A number of previous studies suggested that large ownership influenced capital structure decisions by controlling the conflicts that occurred between managers and shareholders. However, the empirical evidence of this relation has not been consistent and clear as yet. It was stated that block holders can enhance the quality of corporate governance and increase manager efficiency by monitoring managers, which may determine the debt level [19] [20]. Specifically, in firms with dispersed ownership and control, small shareholders have less motivation to monitor managers, and less influence, because they hold a small proportion of shares and the loss caused by manager discretion is shared among many investors.

In addition, the cost of having information and monitoring may outweigh its benefits. Conversely, in firms with concentrated ownership, large shareholders have both motivation and power to monitor managers to protect their investments [19] [20]. Supporting this idea, it was argued that block holders play an active role in firm performance. Large investors can take control of the firm, re-place managers or cut managers' benefits if the firm's performance is poor [21] [22].

As a consequence, large ownership could serve as an alternative for debt financing to boost the monitoring of managers. It was explained that the negative relation between debt level and large ownership using the signaling view. They argued that the presence of larger shareholders can work as an effective signal to the market that managers will act in the best interests of the shareholders, thereby reducing the conflicts between managers and shareholders [20]. Depending on the above discussion, the next hypothesis was developed;

$H 4$ There is a significant relationship between block ownership and capital structure.

\subsection{Institutional Ownership and Capital Structure}

Institutional investors can reduce the agency costs by monitoring the firm's performance and by ensuring the shareholders' interests. Shleifer and Vishny (1986) show that institutional investors successfully monitor the performance of the management team [21] [23] [24]. According to this "active monitoring hypothesis" institutional investors can reduce the scope of managerial opportunism by 
closely monitoring them. Because of their fiduciary position, institutional investors are compelled to monitor the mangers. Their huge stake in the firm provides the economics for doing so.

It was suggested that external block holders have incentives to monitor and influence management appropriately in order to protect their significant investments [4]. The close monitoring of institutional investors may force managers to take decisions in the interests of shareholders. Their ability to purse self-interests may diminish. As a result, managers may be prevented from employing lower levels of debt to protect their employment risk. Hence, we may hypothesize that institutional shareholding and debt levels will be positively related. The empirical literature also shows that institutional shareholding and firm debt level are related.

The active monitoring hypothesis was challenged [24]. He puts forth the argument that large external shareholders may be passive voters. They may collude with insiders against the interests of dispersed shareholders. In line with this argument, [19] presented the "passive voters" hypothesis' by relating the large shareholders and firm value. If this happens to be the behavior of institutional investors then institutional shareholding and debt level may be negatively related to each other. Depending on the above discussion, the next hypothesis was developed;

$H 5$ There is a significant relationship between Institutional ownership and capital structure.

\subsection{Ownership Concentrations on Capital Structure}

There is increased empirical evidence of ownership structure on capital structure in developing and emerging markets. The contrary result with [25] may be the differences of shareholder protection in developed and developing countries. At low level of ownership concentration, shareholders are more risk averse as their undiversified features, they tend to use less debt to reduce any financial distress. With the high level of concentrated ownership, firms tend to issue more debt to avoid losing control.

It was investigated that the capital structure determinants of four Asia Pacific countries, the result shows that the leverage is positively related with ownership concentration in three of four countries, which family holding dominates a significant proportion. The close relationship between owners and debt holders reduces agency costs of debt and thus easier access for borrowing [26].

The effects of ownership structures on capital structure was examined in East Asian countries and found a positive relationship between ownership concentration and leverage in family firms in Indonesia, Malaysia and Thailand. Large shareholders prefer debt financing to avoid ownership dilution [27].

More and more scholars pay attention to the impact of ownership structure on capital structure choice of Chinese firms. The corporate financing policy of Chinese listed firms from 1995 to 2001 was studied, the results illustrate a U-shape non-linear relationship between largest shareholding and leverage. The high level of controlling largest shareholding corresponds to lower level of leve- 
rage. The result confirms the expropriation hypothesis of largest shareholders on minority shareholders [28].

However, choice of Chinese listed firms and report a negative relationship of ownership when largest shareholder possesses more than certain percentage of firm shares, there is a positive relation. The effect of ownership structure on leverage concentration with firm's leverage was examined. The result is consistent with expropriation hypothesis that largest shareholders are apt to use equity financing to expropriate minority shareholders [29]. Depending on the above discussion, the next hypothesis was developed;

H6 There is a significant relationship between Ownership concentration and capital structure

\section{Research Methodology}

\subsection{Data Collection and Sample Selection}

The sample consists of 50 most active companies on Egyptian stock exchange from 2012 to 2017, which are 50 firms belong to 12 sectors, which are Basic Resources, Chemicals, Construction and Materials, Food and Beverage, Healthcare and Pharmaceuticals, industrial Goods and Services and Automobiles, Real Estate etc. In this study the researcher excludes the banking and insurance sectors because the characteristics of these firms are different from the firms in other industrial sectors in terms of specialized in nature and were subject to different regulations, tax and accounting rules [30]. The final sample consists of 37 firms

\subsection{Variables and Measurement}

The variables used in this study can be categorized into three main types which are; the dependent, independent variables and control variables.

\subsubsection{Dependent Variable}

The dependent variable for this study is the capital structure of firms in the Egyptian market. The capital structure will be measured by the long-term debt to asset ratio, short-term debt to asset ratio, debt equity ratio and total debt.

\subsubsection{Independent Variable}

There are sex independent variables that will be measured. These are State ownership, foreign ownership, Managerial ownership, institutional ownership (measured by the percentage of ordinary shares held by every ownership), block ownership (measured by the percentage of shares held by large investors who hold at least 5\% of shares) and Ownership Concentration (the proportion of largest shareholder to total shares).

\subsubsection{Control Variables}

The main emphasis of our research is the impact of ownership structure on capital structure. But some variables still influence firm's capital structure and would probably disturb out test, such as firm size, firm age [2]. Thus, there fac- 
tors are set as control variables in regression analysis. We use the natural logarithm of total assets to measure firm size. Firm age is measured in years since establishment.

This research tried to look at the possibility of the relationship between dependent variable and independent variables. The relationship between dependent variable and independent variables is explained in Figure 1.

\subsection{Research Model}

Capital Structure $=\beta 0+\beta 1$ Managerial Ownership $+\beta 2$ Foreign Ownership + $\beta 3$ Block Holder $+\beta 4$ Ownership Concentration $+\beta 5$ Institutional Ownership + $\beta 6$ State Ownership $+\beta 7$ Company Size $+\beta 8$ Age of Company $+\mathrm{e}$

\section{Noting:}

$$
\begin{aligned}
& \beta 0=\text { Regression constant } \\
& \beta 1=\text { Regression coefficient for Managerial Ownership } \\
& \beta 2=\text { Regression coefficient for Foreign Ownership } \\
& \beta 3=\text { Regression coefficient for Block Holders } \\
& \beta 4=\text { Regression coefficient for Ownership Concentration } \\
& \beta 5=\text { Regression coefficient for Institutional Ownership } \\
& \beta 6=\text { Regression coefficient for Company Size } \\
& \beta 7=\text { Regression coefficient for Age of Company } \\
& \mathrm{e}=\text { the error term. }
\end{aligned}
$$

\section{Descriptive Statistics}

This section deals with the descriptive statistics for the data that used in the analysis of this study. Some of the main features of the data will be described quantitatively (e.g. central tendency of the statistics, such as: mean, max and min; data dispersion, such as: standard deviation). The whole table for the descriptive statistics of this study is presented through the following sections.

\section{Summary, Conclusion and Recommendations}

This study examines the relationship between ownership structure and capital structure in an emerging economy such as Egypt. Figure 2 illustrates all significant regressions only depending on pooled regression models. Regarding previous tables (Tables 1-3), ownership concentration is the only variable of ownership structure that has a significant relationship with capital structure variables, as the correspondent $\mathrm{P}$-values $=0.000$.

\section{Contributions and Originality}

This section represents contributions and importance of this research. This research was considered as the first to examine the effect of ownership structure on capital structure after the revolution in Egypt. This research contributes to many fields, whether for the academic or the practical side. For the academic side, it has two contributions: 
Table 1. Presents a summary for all the variables including the dependent, independent and control variables of the study.

\begin{tabular}{|c|c|c|}
\hline Research Variable & Variables & Measurement \\
\hline \multirow{6}{*}{ Ownership Structure } & Managerial Ownership & $\begin{array}{l}\text { The number share owned by managers directly and } \\
\text { indirectly/the total outstanding share }\end{array}$ \\
\hline & State Ownership & $\begin{array}{l}\text { Percentage of shares held by state to the total number } \\
\text { of shareholders. }\end{array}$ \\
\hline & Foreign Ownership & Percentage of shares owned by foreign investors \\
\hline & Block holders & $\begin{array}{l}\text { Percentage of shareholders who owns at least } 5 \% \text { of } \\
\text { the stock to the total number of shareholders. }\end{array}$ \\
\hline & $\begin{array}{l}\text { Ownership } \\
\text { Concentration }\end{array}$ & $\begin{array}{l}\text { Percentage of ownership shares (votes) of the largest } \\
\text { shareholder }\end{array}$ \\
\hline & $\begin{array}{l}\text { Institutional } \\
\text { Ownership }\end{array}$ & $\begin{array}{l}\text { Percentage of shares held by institutions (e.g., } \\
\text { pension funds) }\end{array}$ \\
\hline \multirow{4}{*}{ Capital Structure } & $\begin{array}{l}\text { Long-term debt to total } \\
\text { assets }\end{array}$ & Long-term debt/total assets \\
\hline & $\begin{array}{l}\text { Short-term debt to total } \\
\text { assets }\end{array}$ & Short-term debt/total assets \\
\hline & Debt to Equity & Total debt/Equity \\
\hline & Total debts & Short Term debt + Long Term debt \\
\hline Firm Size & $\begin{array}{l}\text { The natural log of total } \\
\text { assets }\end{array}$ & \\
\hline Firm Age & $\begin{array}{l}\text { The natural log of the } \\
\text { number of years since } \\
\text { establishment }\end{array}$ & \\
\hline
\end{tabular}

Table 2. Summary for descriptive statistics of variables.

\begin{tabular}{|c|c|c|c|c|c|c|}
\hline & Range & Minimum & Maximum & Mean & Std. Deviation & Variance \\
\hline $\begin{array}{l}\text { Managerial } \\
\text { Ownership }\end{array}$ & 0.92 & 0.00 & 0.92 & 0.1630 & 0.26093 & 0.068 \\
\hline $\begin{array}{c}\text { Foreign } \\
\text { Ownership }\end{array}$ & 1.00 & 0.00 & 1.00 & 0.5984 & 0.22071 & 0.049 \\
\hline $\begin{array}{c}\text { Ownership } \\
\text { Concentration }\end{array}$ & 0.17 & 0.00 & 0.17 & 0.0161 & 0.03494 & 0.001 \\
\hline $\begin{array}{l}\text { Institutional } \\
\text { Ownership }\end{array}$ & 1 & 0 & 1 & 0.58 & 0.273 & 0.075 \\
\hline Block Holders & 0.8999 & 0.1001 & 1.0000 & 0.605987 & 0.2113998 & 0.045 \\
\hline Company size & 40,470 & 25,53 & 40,470 & 36,197 & 52,777 & 27,855 \\
\hline Firm Age & 77.00 & 0.00 & 77.00 & 26.9200 & 18.68701 & 349.204 \\
\hline $\begin{array}{c}\text { Long Term } \\
\text { debt to asset ratio }\end{array}$ & 26.99 & 0.00 & 26.99 & 0.2068 & 1.60185 & 2.566 \\
\hline $\begin{array}{c}\text { Short Term } \\
\text { debt to asset ratio }\end{array}$ & 5.04 & 0.00 & 5.04 & 0.3231 & 0.44674 & 0.200 \\
\hline Debt equity ratio & 298.00 & -21.67 & 276.34 & 2.6548 & 16.98861 & 288.613 \\
\hline Total debt & 18,277 & 0.00 & 18,277 & 14,768 & 27,339 & 74,743 \\
\hline
\end{tabular}


Table 3. Summary of hypotheses results.

\begin{tabular}{lll}
\hline Hypotheses & Description & Results \\
\hline $\mathrm{H}_{1}$ & $\begin{array}{l}\text { There is a significant relationship between ownership structure } \\
\text { and Long-term debt }\end{array}$ & Partially Supported \\
$\mathrm{H}_{2}$ & $\begin{array}{l}\text { There is a significant relationship between ownership structure } \\
\text { and Short-term debt }\end{array}$ & Not Supported \\
$\mathrm{H}_{3}$ & $\begin{array}{l}\text { There is a significant relationship between ownership structure } \\
\text { and debt equity ratio }\end{array}$ & Partially Supported \\
$\mathrm{H}_{4}$ & $\begin{array}{l}\text { There is a significant relationship between ownership structure } \\
\text { and total debt }\end{array}$ & Partially Supported \\
\hline
\end{tabular}

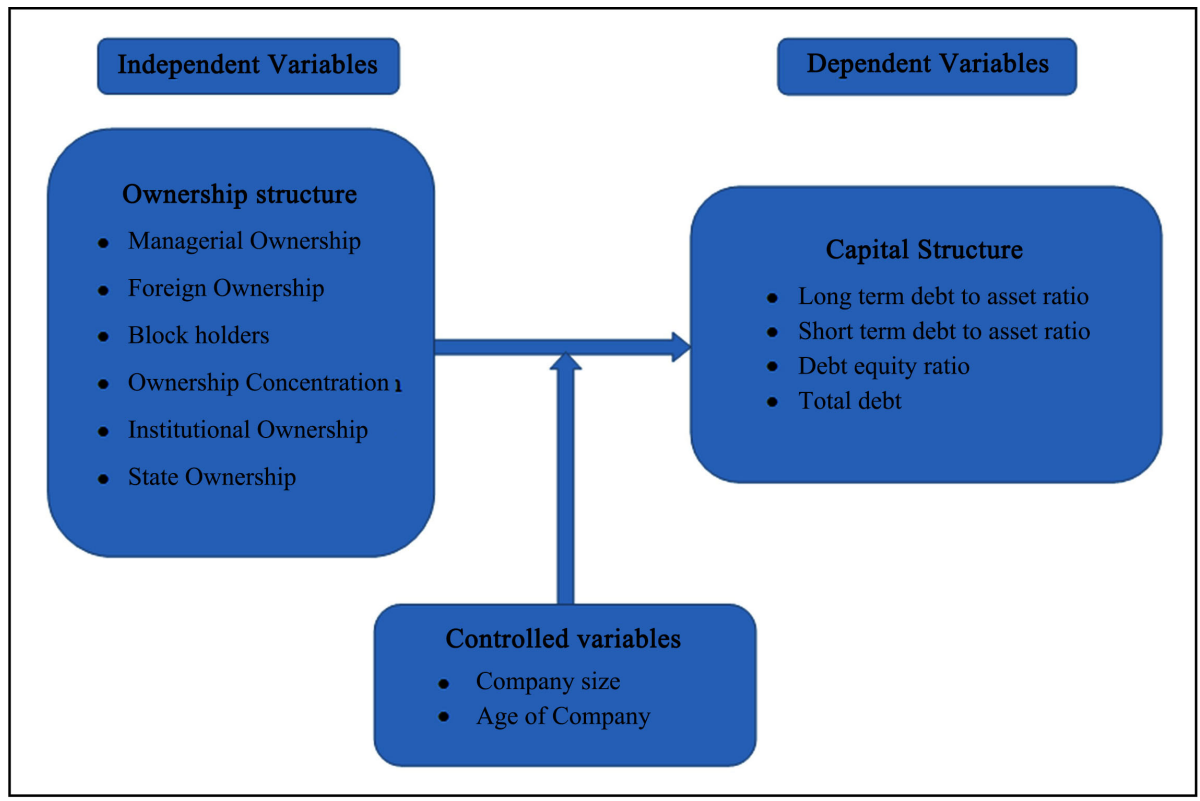

Figure 1. Relationship diagram between independent variables and dependent variable.

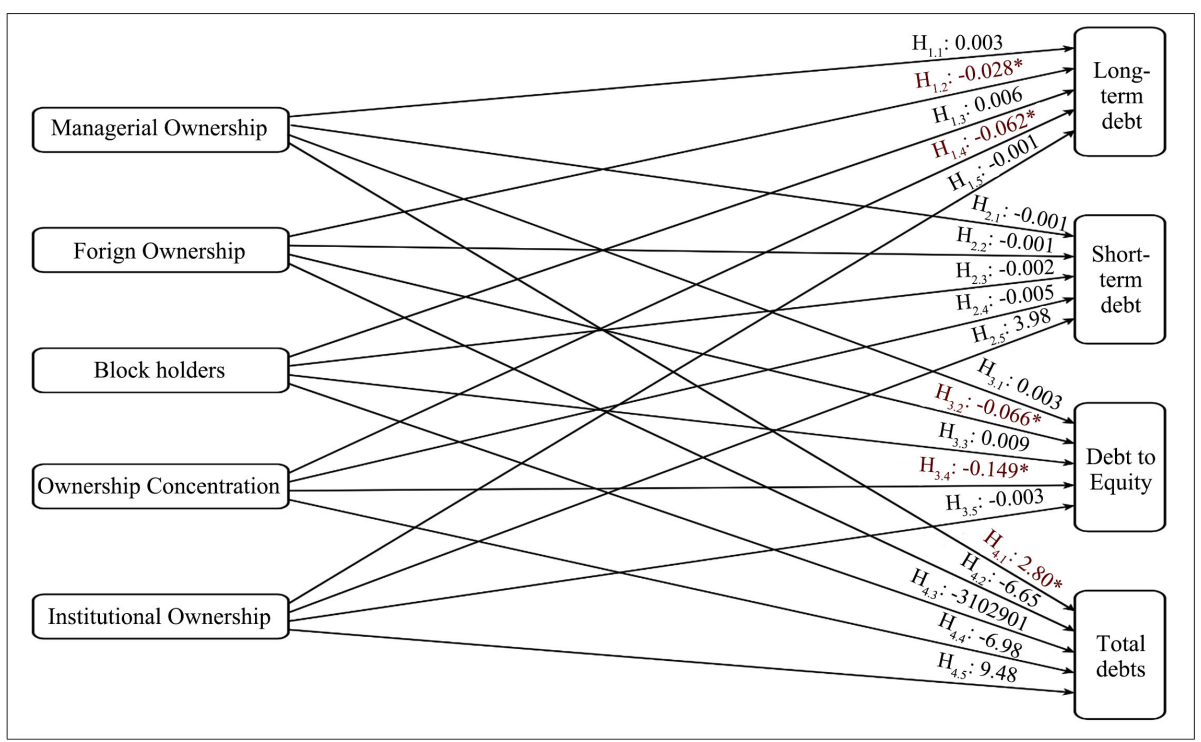

Figure 2. The tested model. 
1) It contributes to theoretical knowledge by providing a full picture of the influence of ownership structure on capital structure, as it is one of the first studies to identify the relationship between different aspects of ownership structure (managerial, state, foreign and block holders) and capital structure. On other words, it extends the literature by investigating whether ownership structure can explain variation in capital structure.

2) This research seeks to fill the gap of measuring relationships in an emerging economy such as Egypt. It is examining the relationship between ownership structure and capital structure in Egypt by investigating the impact of ownership concentration and its different categories (managerial ownership, state ownership, foreign ownership, block ownership, institutional ownership and ownership concentration) on capital structure of the most active 50 non-financial Egyptian listed companies for the period 2012-2017.

Finally, in a practical wise, stock market authorities in Egypt could employ this research to evaluate the current impact of ownership structure on capital structure and to develop regulations and recommendations that correct its way for the desired one in order to make the Egyptian market more attractive to investors.

\section{Recommendation}

It is recommended to consider firms outside Egypt as well as enlarging the sample size in the future, as this research was applied on top 50 companies listed in the Egypt Stock Exchange only and as a result the research recommendations might be negatively affected which may lead to inappropriate recommendations.

Furthermore, the time interval under study might be considered in the future researches to be larger period as in our research only the period from 2012 to 2017 was examined. Also, it could be considered to make a comparative study between the period before the revolution and after it.

\section{Limitations}

This section illustrates the limitations of this research in order to try to avoid the in other researches and works to get more reliable results. The limitations of this research are as follow. First this research is limited to Egypt as an example to a developing country and doesn't include any other developing county, also, this research is only including the top Nonfinancial Companies during the period 2012-2017, while doesn't include other companies due to the lack of the data before 2012. Moreover, the lack of data of State Ownership in the Egyptian Stock market data caused to exclude it from the analysis as an independent variable in the ownership structure. Finally, the theoretical framework used in this research is limited to the chosen variables as those variables are the only one that their data are available in the Egyptian stock market.

\section{Conflicts of Interest}

The authors declare no conflicts of interest regarding the publication of this paper. 


\section{References}

[1] Jensen, M.C. and Meckling, W.H. (1976) Theory of the Firm: Managerial Behavior, Agency Costs and Ownership Structure. Journal of Financial Economics, 3, 305-360. https://doi.org/10.1016/0304-405X(76)90026-X

[2] Zheka, V. (2005) Corporate Governance, Ownership Structure and Corporate Efficiency: The Case of Ukraine. Managerial and Decision Economics, 26, 451-460. https://doi.org/10.1002/mde.1258

[3] Bajaj, M., Chan, Y.S. and Dasgupta, S. (1998) The Relationship between Ownership, Financing Decisions and Firm Performance: A Signaling Model. International Economic Review, 39, 723-744. https://doi.org/10.2307/2527397

[4] Friend, I. and Lang, L.H.P. (1988) An Empirical Test of the Impact of Managerial Self-Interest on Corporate Capital Structure. Journal of Finance, 47, 271-281. https://doi.org/10.2307/2328459

[5] Brailsford, T.J., Oliver, B.R. and Pua, S.L. (2002) On the Relation between Ownership Structure and Capital Structure. Accounting \& Finance, 42, 1-26. https://doi.org/10.1111/1467-629X.00001

[6] Pindado, J. and de La Torre, C. (2011) Capital Structure: New Evidence from the Ownership Structure. International Review of Finance, 11, 213-226.

https://doi.org/10.1111/j.1468-2443.2010.01115.x

[7] Brealey, R., Leland, H.E. and Pyle, D.H. (1977) Informational Asymmetries, Financial Structure, and Financial Intermediation. The Journal of Finance, 32, 371-387. https://doi.org/10.1111/j.1540-6261.1977.tb03277.x

[8] Berger, P.G., Ofek, E. and Yermack, D.L. (1997) Managerial Entrenchment and Capital Structure Decisions. The Journal of Finance, 52, 1411-1438.

https://doi.org/10.1111/j.1540-6261.1997.tb01115.x

[9] Wen, Y., Rwegasira, K. and Bilderbeek, J. (2002) Corporate Governance and Capital Structure Decisions of the Chinese Listed Firms. Corporate Governance: An International Review, 10, 75-83. https://doi.org/10.1111/1467-8683.00271

[10] Morck, R., Shleifer, A. and Vishny, R.W. (1988) Management Ownership and Market Valuation: An Empirical Analysis. Journal of Financial Economics, 20, 293-315. https://doi.org/10.1016/0304-405X(88)90048-7

[11] Mishra, C.S. and McConaughy, D.L. (1999) Founding Family Control and Capital Structure: The Risk of Loss of Control and the Aversion to Debt. Entrepreneurship Theory and Practice, 23, 53-64. https://doi.org/10.1177/104225879902300404

[12] Ghaddar, S. (2004) Ownership Variables and Capital Structure: Evidence from Chile.

[13] Harris, M. and Raviv, A. (1988) Corporate Control Contests and Capital Structure. Journal of Financial Economics, 20, 55-86. https://doi.org/10.1016/0304-405X(88)90040-2

[14] Kim, W.S. and Sorensen, E.H. (1986) Evidence on the Impact of the Agency Costs of Debt on Corporate Debt Policy. Journal of Financial and Quantitative Analysis, 21, 131-144. https://doi.org/10.2307/2330733

[15] Zou, H. and Xiao, J.Z. (2006) The Financing Behaviour of Listed Chinese Firms. The British Accounting Review, 38, 239-258. https://doi.org/10.1016/j.bar.2006.04.008

[16] Li, K., Yue, H. and Zhao, L. (2009) Ownership, Institutions, and Capital Structure: Evidence from China. Journal of Comparative Economics, 37, 471-490. https://doi.org/10.1016/j.jce.2009.07.001 
[17] Pöyry, S. and Maury, B. (2010) Influential Ownership and Capital Structure. Managerial and Decision Economics, 31, 311-324.

[18] Gurunlu, M. and Gursoy, G. (2010) The Influence of Foreign Ownership on Capital Structure of Non-Financial Firms: Evidence from Istanbul Stock Exchange. IUP Journal of Corporate Governance, 9, 21.

[19] McConnell, J.J. and Servaes, H. (1990) Additional Evidence on Equity Ownership and Corporate Value. Journal of Financial Economics, 27, 595-612. https://doi.org/10.1016/0304-405X(90)90069-C

[20] Zeckhauser, R.J. and Pound, J. (1990) Are Large Shareholders Effective Monitors? An Investigation of Share Ownership and Corporate Performance. In: Asymmetric Information, Corporate Finance, and Investment, University of Chicago Press, Chicago, 149-180.

[21] Shleifer, A. and Vishny, R.W. (1986) Large Shareholders and Corporate Control. Journal of Political Economy, 94, 461-488. https://doi.org/10.1086/261385

[22] Wiwattanakantang, Y. (1999) An Empirical Study on the Determinants of the Capital Structure of Thai Firms. Pacific-Basin Finance Journal, 7, 371-403.

https://doi.org/10.1016/S0927-538X(99)00007-4

[23] Jensen, M.C. (1986) Agency Costs of Free Cash Flow, Corporate Finance, and Takeovers. The American Economic Review, 76, 323-329.

[24] Pound, J. (1988) Proxy Contests and the Efficiency of Shareholder Oversight. Journal of Financial Economics, 20, 237-265.

https://doi.org/10.1016/0304-405X(88)90046-3

[25] de La Bruslerie, H. and Latrous, I. (2012) Ownership Structure and Debt Leverage: Empirical Test of a Trade-Off Hypothesis on French Firms. Journal of Multinational Financial Management, 22, 111-130. https://doi.org/10.1016/j.mulfin.2012.06.001

[26] Deesomsak, R., Paudyal, K. and Pescetto, G. (2004) The Determinants of Capital Structure: Evidence from the Asia Pacific Region. Journal of Multinational Financial Management, 14, 387-405. https://doi.org/10.1016/j.mulfin.2004.03.001

[27] Driffield, N., Mahambare, V. and Pal, S. (2007) How Does Ownership Structure Affect Capital Structure and Firm Value? Recent Evidence from East Asia. Economics of Transition, 15, 535-573. https://doi.org/10.1111/j.1468-0351.2007.00291.x

[28] Shi, Y. (2010) Corporate Financing Policy under Large Shareholder's Control: Evidence from Chinese Listed Companies. https://doi.org/10.2139/ssrn.1547663

[29] Liu, Q., Tian, G. and Wang, X. (2011) The Effect of Ownership Structure on Leverage Decision: New Evidence from Chinese Listed Firms. Journal of the Asia Pacific Economy, 16, 254-276. https://doi.org/10.1080/13547860.2011.564755

[30] Zeitun, R. and Tian, G.G. (2007) Capital Structure and Firm Performance: Evidence from Jordan. Australia Accounting Business and Finance Journal, 1, 148-168. https://doi.org/10.14453/aabfj.v1i4.3 